\title{
Development of Road and Bridge Infrastructure to Enhance Economic Growth in the Coastal Communities of Tuminting District in Manado City
}

\author{
Fandy Latuni \\ Faculty of Economics Nusantara University, Manado, Indonesia \\ http://dx.doi.org/10.18415/ijmmu.v6i5.1143
}

\begin{abstract}
Overcoming poorness in town of Manado which pursuant to statistical which is tendency mount, with year data 2016 noted by number $22,41 \%$. Various means done by government of town of Manado in improving to get society like developing infrastructure walke and recognized bridge by way of Boulevard 2 with length walke $6,5 \mathrm{~km}$ and wide $14 \mathrm{~m}$ very expected can grow economic sentra sentra newly to coastal area society through the street boulevard 2 . Target of research is wishing to know do development of infrastructure walke and bridge of Boulevard 2 looking positive to make-up of coastal area society economics in district of Tuminting town of Manado. Pursuant to result of research that development of infrastructure walke and bridge of Boulevard 2 having relation 98,5\% with make-up of coastal coastal area society economics of district of Tuminting town of Manado.
\end{abstract}

Keywords: Infrastructure; Economic Growth

\section{Introduction}

The city of Manado is on the northern tip of the island of Sulawesi and is the largest city in the province of North Sulawesi as well as the provincial capital. Geographically, it is located between $1025^{\prime}$ $88^{\prime \prime}-1039^{\prime} 50^{\prime \prime} \mathrm{LU}$ and $124047^{\prime} 00^{\prime \prime}-1240$ 56' 00" BT. And is administratively bordered by:

- North side is bordered by North Minahasa Regency

- South side is bordered by Minahasa Regency

- East side is bordered by North Minahasa Regency and Minahasa Regency

- West side borders the Sulawesi Sea

The city of Manado is inhabited by several large ethnic groups from North Sulawesi including Minahasa, Bolaang Mongondow and Sangihe-Talaud and various religious groups with the majority of the population of Manado being Christian. Even though Manado City is inhabited by various ethnicities and various religious groups, the people of Manado City always live in harmony and peace. Torang Samua Basudara's slogan seems to strengthen the harmony of life in the city of Manado. No wonder some national figures say that Manado is a miniature of Indonesia. 
The city of Manado is inhabited by several large ethnic groups from North Sulawesi including Minahasa, Bolaang Mongondow and Sangihe-Talaud and various religious groups with the majority of the population of Manado being Christian. Even though Manado City is inhabited by various ethnicities and various religious groups, the people of Manado City always live in harmony and peace. Torang Samua Basudara's slogan seems to strengthen the harmony of life in the city of Manado. No wonder some national figures say that Manado is a miniature of Indonesia.

Behind all the beauty of the city of Manado stored several problems including waste problems where the development of the volume of waste in the city of Manado that was reported in 2011 amounted to 828,812 cubic meters, in 2012 increased 840,960 cubic meters, in 2013 to 940,703 cubic meters and in 2014 increased to 980,865 cubic meters. The increase in the volume of waste is caused by the growth of the population of Manado, which continues to increase from year to year affecting the condition of the landfill (Final Disposal Place) located in the village of Sumompo which covers only 74,593 square meters. This landfill is no longer able to accommodate the amount of waste transported from 87 villages in the city of Manado.

Criminal Problems where recorded in 2014 there were 1,696 cases including 4 cases of arson, 7 cases of rape, 30 cases of murder, 44 cases of fraud, 11 cases of fraud, 17 cases of drugs, and 89 cases of domestic violence.

While the problem of poverty is no less important to be addressed immediately. From the data of the poor population of the city of Manado from 2004 to 2016, relatively increased, and is still above $20 \%$ of the population of the city of Manado, in 2004 the number of poor people was in the range of $16.14 \%$, and in 2010 the poor population had increased to $26.72 \%$ and in 2016 at $22.41 \%$.

Overcoming the poverty problem the Manado City government implemented the construction of road infrastructure on the coast of the city of Manado, by building the Soekarno bridge that connects the Tuminting sub-district with the downtown area. Even the construction of Boulevard 2 road that extends along the coast from Sindulang 1, Sindulang 2, Karangria, and even now is also connected to the Maasing and Tumumpa villages.

This road and bridge infrastructure development is certainly expected to bring economic change to the people of Manado City. Especially the coastal community which is usually known as a relatively poor fishing settlement.

From the description of the problems above, it can be raised the title of the research "Development of Road and Bridge Infrastructure for enhancing the economic growth of coastal communities in Tuminting District in Manado City".

Understanding Infrastructure is listed in several versions. Understanding Infrastructure according to the American Public Works Association (Stone, 1974 in Kodoatie, RJ, 2005), are physical facilities developed or needed by public agencies for government functions in the supply of water, electricity, waste disposal, transportation and similar services to facilitate social and economic goals. So infrastructure is a physical system that is needed to meet basic human needs in the social and economic sphere.

Based on the concepts and definitions of infrastructure above, infrastructure can generally be said to include public facilities built by central and local governments as servants for the community in overcoming the effects of non-working market mechanisms and to support and encourage economic and social activities of a community. 
Road infrastructure is a land transportation infrastructure that covers all parts of the road, including complementary buildings and equipment intended for traffic that is on the surface of the land, below the surface of the land and / or water, and above the water surface, except railroad tracks, lorries, and cable road.

The existence of a good road is a basic requirement that must be met to support the growth of an urban area. In addition, the road aims to support mobility of goods and passengers between the city center and industrial and service areas, offices, and residential and residential areas as well as suburban areas (hinterland).

Roads have a purpose and function for the economy of a region. The objectives and functions include:

1. The function of opening access (land access) where with the existence of roads can open access or access points from one region to another. This function is very important to increase GRDP and reduce areas that are lagging behind in terms of the economy.

2. Community Service Function (Road service) where the Road serves to service for the community. In this function the road can provide services - services in the process of product distribution, marketing or other community and economic activities.

3. The function of population exchange and long distance transportation (interchange community and long distance transportation). The function of this road is important for large areas of the country due to the development of motor vehicle technology, especially for long distance transportation.

\section{Methodology}

\section{a. Research variable}

1) Independent Variables Independent variables that are denoted by $(X)$ are variables that affect the dependent variable, both those that have positive effects and those that have negative effects (Ferdinand, 2006: 26). The independent variable in this study is Road Infrastructure.

2) Dependent Variables Dependent variables are variables that are the main focus of research. In this research, the dependent variable is the Growth of Coastal Communities (Y)

\section{b. Variable Operational Definitions and Variable Indicators}

The operational definition of a variable is a definition of a variable that is formulated based on the characteristics of the variable that can be observed (Azwar, 1997) while Indrianto and Supomo (2001) state the operational definition is the determination of the construct so that it becomes a variable that can be measured. The operational definitions are as follows:

1) Road Infrastructure Development is a land transportation infrastructure that covers all parts of the road, including complementary buildings and equipment intended for traffic that is on the surface of the land, below the surface of the land and / or water, and above the water surface, except railways, lorries, and cable road. Indicators of Road Infrastructure include:

a) road infrastructure

b) bridge infrastructure 
c) transportation facilities

2) The economic growth of coastal communities is as a "long-term increase in the ability of an area to provide more and more types of economic goods to its inhabitants; this ability grows in accordance with technological advances, and the institutional and ideological adjustments that it needs. Indicator of community economic growth:
a) Real National Income
b) Real Per capita Income
c) Population Welfare
d) Labor

\section{c. Place and time of research}

In this study, the authors chose Tuminting District because it was just completed Boulevard 2 road infrastructure that connects the Central City Region to the Tumumpa 2 District of Manado. The time of the study is scheduled for 2018 for 3 months, starting in January and the plan will end in March 2018.

\section{d. Data Types and Sources}

1) Types of Data

a) Qualitative data namely qualitative analysis is a form of analysis based on the data stated in the form of description. This qualitative analysis is used to discuss and explain the results of research on various symptoms or cases that can be described in sentences.

b) Quantitative data is ordinal data obtained from the results of questionnaires that were translated using a Likert scale. The processing methods are as follows:

(1)Editing (Editing) Selecting or retrieving data that is necessary and discard data that is deemed unnecessary, to facilitate calculations in testing hypotheses.

(2) Coding (Giving Code) The process of giving certain codes to the types of questionnaires for groups into the same category.

(3) Scoring (Scoring) Scoring is an activity in the form of research or expectations in the form of quantitative figures needed in the calculation of hypotheses. Or change qualitative data into quantitative form

2) Data source

a) Primary Data, that is data obtained through research in the field both through respondents and observations.

b) Secondary data, i.e. data obtained from the readings from books, magazines, papers and other literature as well as browsing the internet that has to do with the problems encountered.

\section{e. Population and Samples}

1) Population

The source of data in research is often referred to as the study population. The definition of population according to Husein Umar (2002) is: as a collection of elements that have certain characteristics that are the same and have the same opportunity to be selected as sample members ". The population in this study are all people who live on the coast in Tuminting sub-district.

2) Sample.

The sample according to Husein Umar (2002) is as follows: "the sample is part of the population". As for the sampling technique using the accidental sampling method. Where according to Arikunto (2002) accidental sampling is taking respondents as a sample based on needs, ie anyone who 
happens to meet with researchers can be used as a sample if people who happen to be met are suitable as data sources. The number of samples in this study amounted to 50 people, and this is considered quite representative because of the nature of the homogeneity of the community.

\section{f. Method of collecting data}

To find the data and information needed, the following techniques are used:

1) Liberary Research, namely by finding and collecting data from literature that has to do with the problem under study.

2) Field research, namely research used in the field, the data is obtained by:

a) Using a list of questions (questionnaires) that have been prepared in advance

b) Interview, which is asking questions verbally and directly

c) Observation, which is a data collection technique by direct observation of the object under study.

\section{g. Data analysis method}

In this case the authors do it using statistical analysis to analyze the qualitative data, that is by reading the table tables, graphs / figures provided and then doing a description and interpretation. In this case the data is seen in the questionnaire filled out by the respondent. The questionnaire is qualitative in nature and then quantified by giving a score (value) using the Likert scale as follows: Strongly agree to be rated (5), Agree to be given a value of 4, Quite agree to be given a value of 3, Disagree to be rated 2 and Strongly disagree to be rated 1.

The data collected will be analyzed using statistical analysis techniques using the SPSS 22 program. The methods used in this study are:

\subsubsection{Simple Regression Method}

Simple regression is used by researchers to see the effect of road infrastructure on the Coastal Community Economic Growth in Tuminting sub-district, Manado City

a simple regression formula is used, namely $\mathrm{Y}=\mathrm{a}+\mathrm{bx}$

Where :

$\mathrm{Y}=$ Coastal Community Economic Growth in the districtTuminting City of Manado

$\mathrm{X}=$ Road Infrastructure

$\mathrm{a}=$ constant

$\mathrm{b}=$ regression coefficient

\subsubsection{Correlation analysis $(r)$ and Determination $\left(\mathbf{r}^{2}\right)$.}

Looking at the Relationship of Road Infrastructure to the Economic Growth of Coastal Communities in Tuminting Sub-District, Manado City, correlation analysis is used The basic interpretation is based on the interpretation table guidelines in table 3.1 
Table 3.1

Guidelines for Interpretation of Correlation Coefficients

\begin{tabular}{|c|c|}
\hline Coefficient interval & Relationship Level \\
\hline $0,00-0,199$ & Very low \\
\hline $0,20-0,399$ & Low \\
\hline $0,40-0,599$ & Is \\
\hline $0,60-0,799$ & Strong \\
\hline $0,80-1,000$ & Very Strong \\
\hline
\end{tabular}

Meanwhile, to interpret the value of determination $\left(\mathrm{r}^{2}\right)$ table 3.2 is used below:

Table 3.2

Interpretation Guidelines High and low coefficient of determination

\begin{tabular}{|l|l|}
\hline Statement & Information \\
\hline$<4 \%$ & Very low \\
\hline $5 \%--16 \%$ & Low \\
\hline $17 \%-49 \%$ & Is \\
\hline $50 \%-81 \%$ & Strong \\
\hline $82 \%$ & Very Strong \\
\hline
\end{tabular}

\subsection{Test Reliability and Validity}

\subsubsection{Reliability Test}

Reliability Test is a tool to measure a questionnaire which is an indicator of a variable or construct. A questionnaire is said to be reliable or reliable if one's answers to questions are consistent or stable over time. SPSS provides facilities to measure reliability with the Cronbach Alpha $(\alpha)$ statistical test.

$$
\propto=\frac{k \cdot r}{1+(k-1) r}
$$

Where :

$\alpha=$ reliability coefficient

$\mathrm{r}=$ correlation between items

$\mathrm{k}=$ number of items

\subsubsection{Test Validity}

Validity test is used to measure whether or not a valid questionnaire. A questionnaire is said to be valid if the questions on the questionnaire are able to reveal something that will be measured by the questionnaire. Validity test is done by comparing the value of $r$ arithmetic (for each item can be seen in the column corrected item-total correlations) with $r$ 
table for degree of freedom $(\mathrm{df})=\mathrm{n}-\mathrm{k}$, in this case $\mathrm{n}$ is the number of samples and $\mathrm{k}$ is the number of items. If $r$ arithmetic> $r$ table, then the question is said to be valid (Ghozali, 2005:).

$r x y=\frac{n \sum x y-\left(x^{2}\right)(y)^{2}}{\sqrt{\left\{n \sum x^{2}-\left(\sum x\right)\right\} \sqrt{\left\{\Sigma y^{2}-(\Sigma y)\right\}}}}$

Where :

Rxy = correlation coefficient (r-count)

$\sum \mathrm{x}=$ Score of the independent variable

$\sum \mathrm{y}=$ Score of the dependent variable

$\sum x y=$ Product times the item score with a total score

$\mathrm{n}=$ Number of respondents

\subsection{Hypotensis Testing}

Because the number of samples is 50 , then to test the hypothesis $\mathrm{z}$ test is used to test the significance of the relationship between variables X and Y, does the variable 1 Road Infrastructure Development affect the Economic Growth of Coastal Communities in Tuminting Subdistrict, Manado City

For this reason the research hypothesis is

H0: Road Infrastructure Development has no effect on the Economic Growth of Coastal Communities in Tuminting Sub-District, Manado City

Ha: Road Infrastructure Development affects the Economic Growth of Coastal Communities in Tuminting Sub-District, Manado City

The basis for decision making (Ghozali, 2005) is to use a number of probability probabilities, namely:

1) If the probability value is $>0.05$, then Ho is accepted and Ha is rejected.

2) If the significance value is $<0.05$, then Ho is rejected and Ha is accepted.

\section{Result and Discussion}

After the research questionnaire was conducted by the author, 50 respondents who were the object of the study were scattered in several villages that have areas on the street boulevard 2, such as Sindulang 1, Sindulang 2, Karangria, Maasing and Tumumpa 2 and the results of filling the questionnaire. tabulated and processed using the SPSS version 22 application, the results of the study are as follows:

Tabel 4.5

Descriptive Statistics

\begin{tabular}{|l|l|l|l|}
\hline & Mean & Std. Deviation & $\mathrm{N}$ \\
\hline Economic growth & 28,0200 & 4,42853 & 50 \\
Infrastructure & & & \\
development & 37,4800 & 5,85624 & 50 \\
\hline
\end{tabular}


In Table 4.5 on Descriptive Statistics it can be seen economic growth variables and Infrastructure Development variables. Of the two variables, the average variable (mean) of economic growth of 28.0 with a standard deviation of 4.43 , while the infrastructure development variable the average value (Mean) of 37.48 with a standard deviation of 5.86 with a total sample $(\mathrm{N})$ of 50.

To see the relationship between the research variables described in table 4.6 below:

Tabel 4.6

Variables Entered/Removeda

\begin{tabular}{|l|l|l|l|}
\hline Model & Variables Entered & $\begin{array}{l}\text { Variables } \\
\text { Removed }\end{array}$ & Method \\
\hline 1 & $\begin{array}{l}\text { Infrastructure } \\
\text { development }\end{array}$ & & Enter \\
\hline
\end{tabular}

a. Dependent Variable: Economic growth

b. All requested variables entered.

Based on the data in table 4.6, it shows that in this study the infrastructure development variable is an independent variable or the independent variable of Economic Growth is the dependent variable or the dependent variable.

\subsection{Regression}

Simple regression is used by researchers to see the effect of road infrastructure on the Economic Growth of Coastal Communities in Tuminting sub-district of Manado, a simple regression formula is used, namely $\mathrm{Y}=\mathrm{a}+\mathrm{bx}$

Where :

$\mathrm{Y}=$ Coastal Community Economic Growth in the district

Tuminting City of Manado

$\mathrm{X}=$ Road Infrastructure

$\mathrm{a}=$ constant

$\mathrm{b}=$ regression coefficient

Simple regression equation of the variable Infrastructure development (the independent variable) and economic growth (the dependent variable) with 50 research samples can be seen in table 4.7 about the coefficients below:

Tabel 4.7

Coefficientsa

\begin{tabular}{|l|l|l|l|l|}
\hline \multicolumn{2}{|l|}{$\begin{array}{l}\text { Unstandardized } \\
\text { Coefficients }\end{array}$} & $\begin{array}{l}\text { Standardiz } \\
\text { ed } \\
\text { Coefficien } \\
\text { ts }\end{array}$ & t & Sig. \\
\hline B & $\begin{array}{l}\text { Std. } \\
\text { Error }\end{array}$ & Beta & & \\
\hline,- 116 &, 499 & &,- 232 &, 817 \\
751 &, 013 &, 993 & 57,044 &, 000 \\
\hline
\end{tabular}

a. Dependent Variable: Economic growth 
From table 4.7 above, the regression equation of the variables of infrastructure development and economic growth is $\mathrm{Y}=-116+0.751 \mathrm{X}$, where Variable $\mathrm{X}=$ Infrastructure Development variable and Variavel $\mathrm{Y}=$ economic growth variable.

Regression equation $\mathrm{Y}=-116+0.75 \mathrm{X}$ where -116 constant values which means that if the value of the infrastructure development variable is 0 , then economic growth is -0.116 , which means there is no economic growth, but each additional infrastructure development by 1 unit will increase 0,75 of economic growth, on the contrary if there is a decrease in infrastructure development by 1 unit it will reduce 0.75 of the variable economic growth.

\subsection{Correlation and Determination}

In seeing how strong the relationship between the variables of infrastructure development and economic growth can be seen in table 4.8 regarding the model summary below.

Tabel 4.8

Model Summaryb

\begin{tabular}{|l|l|l|l|l|}
\hline Model & $\mathrm{R}$ & $\mathrm{R}$ Square & $\begin{array}{l}\text { Adjusted } \\
\text { Square }\end{array}$ & $\begin{array}{l}\text { R Std. Error of the } \\
\text { Estimate }\end{array}$ \\
\hline 1 &, $993 \mathrm{a}$ &, 985 &, 985 &, 53947 \\
\hline
\end{tabular}

a. Predictors: (Constant), Infrastructure development

b. Dependent Variable: Economic growth

Looking at the data in table 4.8 , the value of $\mathrm{r}$ is 0.993 which states the large relationship between the variables of infrastructure development and economic growth. To assess whether or not the relationship or correlation between variables expressed as high as 0.993 can be compared with table 3.1 where the number 0.993 is in the range of 0.80 to 1 with a very strong category, this means that the relationship between variables of infrastructure development with economic growth is very strong.

To see the magnitude of the variable of infrastructure development with economic growth or in other words how much the variable of infrastructure development can answer to the variable of economic growth, then based on the data in table 4.8, which states that the value of $\mathrm{r}^{2}$ is 0.985 .

$\mathrm{R}^{2}$ value of 0.985 or $98.5 \%$ if guided by Table 3.2 Interpretation Guidelines High and low coefficient of determination in chapter 3 , the value of 0.985 comes in the range above 0.80 (> $80 \%$ with very strong category) so that the value of $98.5 \%$ is states the relationship between the variables of infrastructure development with economic growth is in the category of Very strong, this means that the variable of infrastructure development can answer the variable of economic growth up to a value of $98.5 \%$ while $1.5 \%$ is influenced by other factors outside of infrastructure development.

\subsection{Hypothesis Testing}

To test the hypothesis as stated in chapter 3, using the $\mathrm{Z}$ test, because the number of samples above 30. With the condition of acceptance of the hypothesis based on the basis of decision making (Ghozali, 2005) is to use a probability probability number, namely:

a. If the probability value is $>0.05$, then Ho is accepted and $\mathrm{Ha}$ is rejected.

b. If the significance value is $<0.05$, then Ho is rejected and Ha is accepted. 
For this reason the research hypothesis is:

$\mathrm{H} 0$ : There is no influence of infrastructure development variables on the economic growth of coastal communities in Tuminting sub-district of Manado city

Ha: The influence of infrastructure development variables on the economic growth of coastal communities in Tuminting sub-district of Manado

To see whether the variable of infrastructure development influences economic growth of coastal communities, it can be seen in table 4.9

Tabel 4.9

Paired Samples Test

\begin{tabular}{|c|c|c|c|c|c|c|c|c|}
\hline & \multicolumn{5}{|c|}{ Paired Differences } & t & \multirow[t]{2}{*}{ df } & \multirow[t]{2}{*}{ Sig. (2-tailed) } \\
\hline & \multirow[b]{2}{*}{ Mean } & \multirow{2}{*}{$\begin{array}{l}\text { Std. } \\
\text { Deviation }\end{array}$} & \multirow{2}{*}{$\begin{array}{l}\text { Std. } \\
\text { Error } \\
\text { Mean }\end{array}$} & \multicolumn{2}{|c|}{$\begin{array}{l}95 \% \text { Confidence } \\
\text { Interval of the } \\
\text { Difference }\end{array}$} & & & \\
\hline & & & & Lower & Upper & & & \\
\hline $\begin{array}{l}\text { Pair } 1 \text { Infrastructure } \\
\text { development } \\
\text { Economic } \\
\text { growth }\end{array}$ & 9,46000 & 1,55459 & ,21985 & 9,01819 & 9,90181 & 43,029 & 49 &, 000 \\
\hline
\end{tabular}

Based on table 4.9 the $\mathrm{Z}$ test is used because the $\mathrm{z}$ test can be seen in the $\mathrm{t}$ test in the number of $\mathrm{n}$ above 30 to test the hypothesis according to Singgih Santoso (2012) in SPSS 20, then the significance value $\mathrm{z}=0,000$ is smaller than alpha of 0.05 or $5 \%$, then we hereby reject Ho which states that there is no influence of infrastructure development variables on the economic growth of coastal communities in Tuminting sub-district of Manado and accept Ha which states that there is an influence of infrastructure development variables on the economic growth of coastal communities in Tuminting sub-district of Manado.

Based on data processing in this study, the results of the study are:

1. Regression Equation between infrastructure development $(\mathrm{X})$ with economic growth $(\mathrm{Y})$ of the coastal community in Tuminting sub-district is $(\mathrm{Y})=-116+0.75 \mathrm{X}$ each additional 1 unit of infrastructure development will increase 0.75 of economic growth, conversely if there is a decrease in infrastructure development by 1 unit it will reduce 0.75 of the variable economic growth.

2. The relationship or correlation ( $\mathrm{r}$ ) between the variable of infrastructure development $(\mathrm{X})$ with the economic growth of the coastal community in Tuminting sub-district is 0.993 which means that the relationship between the variable of infrastructure development and economic growth is very strong.

3. The magnitude of influence (Determination or $\mathrm{r}^{2}$ ) Infrastructure development variable (X) on economic growth (Y) of coastal communities in Tuminting sub-district amounted to 0.985. Or 98.5\% while other factors affecting economic growth of coastal communities in tuminting subdistrict $1.5 \%$. 
4. Rejecting Ho who stated that there was no influence of infrastructure development variables on the economic growth of coastal communities in Tuminting sub-district of Manado city and accepting Ha which stated that there was an influence of infrastructure development variables on the economic growth of coastal communities in Tuminting sub-district of Manado city.

\section{Conclusion}

Based on research that has been done, the conclusions obtained in this study are as follows:

1. The influence of infrastructure development on the economic growth of coastal communities in Tuminting sub-district.

2. A very strong relationship is indicated between infrastructure development and economic growth of the coastal community in Tuminting sub-district.

3. $98.5 \%$ of infrastructure development has an impact on the economic growth of coastal communities in Tuminting sub-district.

\section{Suggestion}

After carrying out the research the quiz gives several suggestions, namely:

1. So that coastal communities can utilize the infrastructure built in order to increase community economic growth.

2. With the development of infrastructure, the NJOP will improve and it is hoped that the community will not be tempted to sell other parties quickly.

3. It is expected that the city government or related parties to multiply infrastructure development in the development because it has a direct impact on the economic growth of the community.

\section{Reference}

Arikunto, S. 2002. Prosedur penelitian: Suatu pendekatan praktek. Edisi revisi. Jakarta: PT Rineka Cipta.

Augusty, Ferdinand. 2006. Metode Penelitian Manajemen: Pedoman Penelitian Untuk Penulisan Skripsi, Tesis dan Disertasi Ilmu Manajemen. Badan Penerbit Universitas Diponegoro. Semarang.

Azwar, Syaifuddin. 2005. Reliabilitas dan Validitas: Interprestasi dan Komputasi. Yogyakarta: Liberty.

Ghozali, imam. 2005. Aplikasi analisis Multivariate Dengan Program SPSS. Semarang: Badan Penerbit Universitas Diponegoro. 
Indriantoro, Nur dan Bambang Supomo. 2011. "Metodologi Penelitian Bisnis Untuk Akuntansi Dan Manajemen", Edisi Pertama. Yogyakarta: BPFE.

Kodoatie, R.J,. 2005. Pengantar Manajemen Infrastruktur. Yogyakarta: Pustaka Pelajar.

Santoso, Singgih. 2012. Panduan Lengkap SPSS Versi 20. Jakarta: PT Elex Media Komputindo.

Umar, Husein. 2002. "Metodologi Penelitian”, Untuk Skripsi dan Tesis Bisnis. Jakarta: PT. Raja Grafindo Persada.

\section{Copyrights}

Copyright for this article is retained by the author(s), with first publication rights granted to the journal.

This is an open-access article distributed under the terms and conditions of the Creative Commons Attribution license (http://creativecommons.org/licenses/by/4.0/). 